\title{
Spontaneous splenic rupture in a patient receiving thrombolytic therapy
}

\author{
Ruptura esplênica espontânea em paciente submetida a terapia \\ trombolítica
}

\author{
Elizabeth Revesz, John A. Grimaldi, Elizabeth T. Clark, Francis J. Podbielski*
}

\begin{abstract}
We describe the case of a 67-year-old female patient with a history of femoral-distal bypass graft with sudden onset of unremitting leg pain, who had recently received tissue plasminogen activator (t-PA). The patient reported non-compliance with her warfarin regimen. Angiography revealed occlusion of the bypass graft. Infusion of t-PA was performed via a right femoral artery approach. On hospital day two, the patient developed nausea and abdominal pain with associated hypotension. A CT scan showed a massive intra-abdominal and pelvic free fluid consistent with blood. The spleen was enlarged and fluid noted around the liver. At laparotomy, a grade III splenic laceration at the hilum was identified and a splenectomy performed. The patient recovered completely. Although rare, spontaneous splenic rupture should be considered in the differential diagnosis of patients undergoing thrombolytic therapy who develop signs of hemodynamic instability.
\end{abstract}

Keywords: Splenic rupture, spontaneous splenic rupture, tissue plasminogen activator, t-PA, thrombolytic therapy.

\section{Introduction}

Spontaneous splenic rupture is an entity that was first described by Atkinson in 1874. ${ }^{1}$ There have been multiple reported cases of spontaneous rupture of the apparently normal spleen. ${ }^{1-10}$ We describe a case of spontaneous splenic rupture that was preceded by the administration of tissue plasminogen activator (t-PA).

\section{Case report}

A 67-year-old female patient previously known to the vascular surgery service presented with a chief complaint of the sudden onset of progressive left lower extremity pain that began 1 week prior to presentation. This pain was first noticed secondary to exercise intolerance and was exacerbated by physical exertion. The pain was described as sharp, unremitting, and localized to the upper

\section{Resumo}

Descrevemos o caso de uma paciente de 67 anos com histórico de enxerto fêmoro-distal com início súbito de dor repetitiva em membro inferior e que havia recebido ativador de plasminogênio tecidual (AP-t) recentemente. A paciente relatou não adesão ao seu tratamento com warfarina. A angiografia revelou oclusão do enxerto. O AP-t foi administrado via artéria femoral direita. No segundo dia de hospitalização, a paciente apresentou náuseas e dor abdominal com hipotensão associada. Uma tomografia computadorizada revelou a existência de um fluido pélvico e intra-abdominal livre em grande quantidade, com suspeita de que fosse sangue. O baço estava crescido, e o fluido foi observado em torno do fígado. A laparotomia identificou uma laceração grau III no hilo esplênico, e uma esplenectomia foi realizada. A paciente teve recuperação completa. Embora rara, a ruptura esplênica espontânea deve ser considerada no diagnóstico diferencial de pacientes submetidos a terapia trombolítica que apresentem sinais de instabilidade hemodinâmica.

Palavras-chave: Ruptura esplênica, ruptura esplênica espontânea, ativador de plasminogênio tecidual, AP-t, terapia trombolítica.

thigh and calf. There was no associated dyspnea or chest pain. The patient reported non-compliance with her warfarin regimen. Past medical history included type II diabetes mellitus, peripheral vascular disease, hypertension, and hypercholesterolemia. Past surgical history was remarkable for a left femoral to anterior tibial bypass graft performed at our institution 2 years prior to this presentation. Medications included warfarin, clonidine, fluvastatin, insulin, and furosemide.

Physical examination was marked by absent pulses in her bypass graft, posterior tibial, and dorsalis pedis arteries. The left foot was notably cooler to the touch when compared with the right foot.

An aortography with bilateral lower extremity views revealed occlusion of the bypass graft. The interventional

\footnotetext{
* Department of Surgery, Resurrection, St. Joseph Hospital, Chicago, Illinois, USA.

No conflicts of interest declared concerning the publication of this article. Manuscript received Nov 10 2008, accepted for publication Mar 112009.

J Vasc Bras. 2009;8(3):274-276.

Copyright $(\odot 2009$ by Sociedade Brasileira de Angiologia e de Cirurgia Vascular
} 
radiology service cannulated the right femoral artery with a 16 French sheath and AngioJet ${ }^{\circledR}$ was performed on the thrombus of the left lower extremity bypass graft followed by the infusion of t-PA. The procedure was successful, and the patient had palpable pulses in the bypass graft, posterior tibial and dorsalis pedis arteries. The patient was admitted to the cardiac intensive care unit for further observation.

The right femoral arterial sheath was removed on hospital day one and an occlusion device deployed at the puncture site. On hospital day two, the patient began to experience abdominal pain associated with nausea. Routine laboratory tests were normal. Hospital day three was marked by worsening nausea and vomiting. The patient also developed a dwindling urine output over the next several hours with a fall in the blood pressure to $80 \mathrm{~mm} / \mathrm{Hg}$ and a reflex tachycardia of 110 to 120 beats per minute. Physical examination revealed a somnolent patient with a diffusely tender but non-distended abdomen. Bowel sounds were distant and hypoactive. There was voluntary guarding, but no rigidity or rebound. After fluid resuscitation, the hemoglobin was found to be $5.2 \mathrm{gm} / \mathrm{dL}$. The patient was transfused with four units of packed red blood cells. The working diagnosis at this time was a retroperitoneal hemorrhage from the puncture site. After stabilization, a CT scan of the abdomen and pelvis revealed massive intra-abdominal and pelvic free fluid consistent with blood. The spleen was enlarged and fluid noted around the liver (Figure 1).

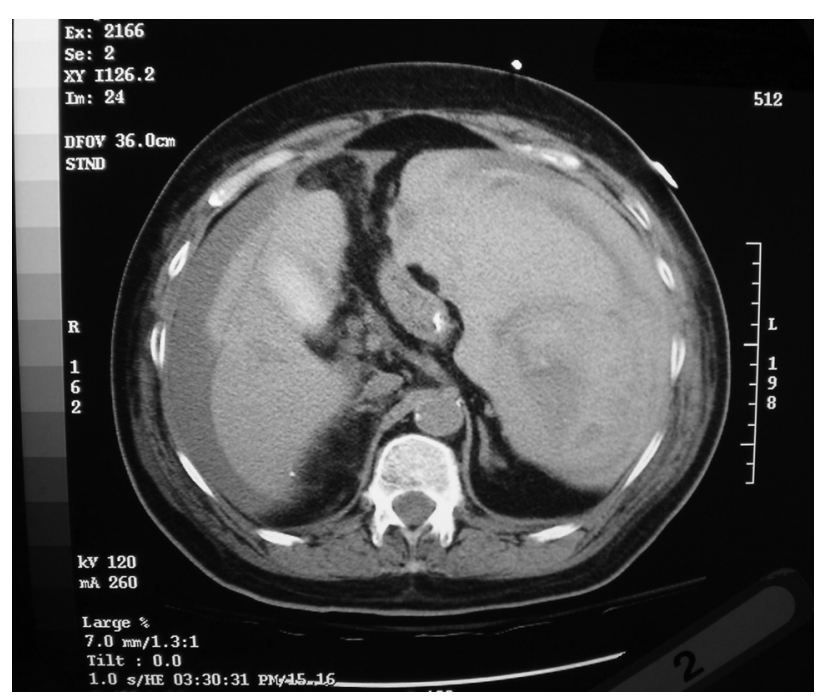

Figure 1 - Image from CT scan showing a grossly abnormal spleen with a large amount of free fluid in the abdominal cavity

\section{Operative management}

This patient was taken to the operating room for emergent laparotomy. After removal of approximately 4 liters of clot, the spleen was examined and found to have a grade III laceration at the hilum. Splenectomy was performed and the patient was transferred to the cardiac care unit where she was extubated on postoperative day zero. The recovery period was marked by development of a large rectus sheath hematoma that was managed conservatively. The patient was discharged on her previous regimen of oral warfarin.

\section{Discussion}

Thrombolysis is a complex process whereby clot is organized and then removed by the proteolytic enzyme, plasmin that converts fibrin to fibrin degradation products. ${ }^{11}$ Thrombolytics such as t-PA are substances that act directly on plasminogen to convert it to plasmin. Because t-PA has specific affinity for fibrin and thus will ideally bind exclusively to pre-formed clots, it should act only on the preexisting fibrin clot for which the patient is being treated and have little effect on peripheral tissues. ${ }^{12}$ This unfortunately is not the case in many instances.

Although disagreement exists regarding the classification of spontaneous splenic rupture, the generally accepted definition is one of disruption of the parenchyma, capsule, or blood supply of a previously normal spleen. ${ }^{13}$ By strict definition, no healthy spleen should rupture. There are myriad reasons that may incite a splenic micro-injury or an injury that would otherwise be subclinical. A multitude of etiologies for spontaneous splenic rupture including coughing, sneezing, movement in bed, and even laughing have been proffered in the literature. In general, any condition that produces splenomegaly can predispose a patient to splenic rupture. A literature search revealed only three case of spontaneous splenic rupture resulting from use of t-PA. ${ }^{3,4}$

The use of t-PA in peripheral arterial occlusion promotes clot dissolution. Considering the demonstrated bleeding complications of t-PA use, the benefit of limb salvage generally outweighs the risk of bleeding. Although rare, spontaneous splenic rupture should be kept in the differential diagnosis in a patient undergoing thrombolytic therapy who develops shock with abdominal pain and distention. While aggressive fluid resuscitation and diagnostic ima- 
ging are the initial steps in management, early surgical intervention may be required to ensure patient survival.

\section{References}

Atkinson E. Death from idiopathic rupture of the spleen. Br Med J. 1874;2:403-4.

Lieberman ME, Levitt A. Spontaneous rupture of the spleen. Am J Emerg Med. 1989;7:28-31.

Blakenship JC, Indeck M. Spontaneous splenic rupture after t-PA for acute myocardial infarction [letter]. N Engl J Med. 1991;325:969.

Cheung PK, Arnold JM, McLarty TD. Splenic hemorrhage: a complication of tissue plasminogen activator treatment. Can J Cardiol. 1990;6:183-5.

Weiner RS, Ong LS. Streptokinase and splenic rupture [brief clinical observation]. Am J Med. 1989;86:249.

Gardner-Medwin J, Sayer J, Mahida YR, Spiller RC. Spontaneous rupture of spleen following streptokinase therapy. Lancet. 1989;2:1398.

Eklof B, Jones JE, Lohi A, Staszkiewicz W, Norgren L. Spontaneous rupture of liver and spleen with severe intra-abdominal bleeding during streptokinase treatment of DVT. Vasa. 1977;6:369-71.
Hibbard LT. Spontaneous rupture of the liver in pregnancy: a report of eight cases. Am J Obstet Gynecol. 1976;126:334-8.

Toubia NT, Tawk MM, Potts RM, Kinasewitz GT. Cough and spontaneous rupture of a normal spleen. Chest. 2005;128:1884-6.

Lennard TW, Burgess P. Vomiting and 'spontaneous' rupture of the spleen. Br J Clin Pract. 1985;39:407, 410.

Kumar, N, A. Robbins \& Cotran pathologic basis of disease. 7th ed. Philadelphia: W.B. Saunders; 2004.

Tissue plasminogen activator for the treatment of acute pulmonary embolism. A collaborative study by the PIOPED Investigators. Chest. 1990;97:528-33.

Brunicardi FC, Andersen DK, Billiar TR, et al. Principles of surgery. 8th ed. New York: McGraw-Hill; 2005.

Correspondence:

Elizabeth Revesz MD

Saint Joseph Hospital

60657 - Chicago, IL - USA

Tel.: +1 (773) 665.6237

Fax: +1 (773) 665.6232

E-mail: e_revesz@yahoo.com,e.revesz@reshealthcare.org 